\title{
УOBOЗНАВCTBO. ПUTEDATУРOЗНАВСТВO
}

УДК 821.111(73) - 1.09"19"

DOI https://doi.org/10.24919/2308-4863/44-2-14

\author{
Ольга ГОРІН, \\ orcid.org/0000-0003-1452-3235 \\ асистент кафедри прикладної лінгвістики \\ Начіонального університету «Львівська політехніка» \\ (Львів, Україна) zabolotna.olha@gmail.com
}

Марта ГАЙДУК,

orcid.org/0000-0003-0392-3268

асистент кафедри прикладної лінгвістики

Національного університету «Львівська політехніка»

(Львів, Україна) marta.s.haiduk@lpnu.иa

Тетяна БРИГА,

orcid.org/0000-0003-3364-7487

старший викладач кафедри прикладної лінгвістики

Національного університету «Львівська політехніка»

(Львів, Україна) tanya.bryga@gmail.com

\section{КОНЦЕПТУАЛЬНО-ПОЕТИЧНА ФУНКЦІЯ ЛЕКСИКИ НА ПОЗНАЧЕННЯ ПРИРОДНИХ СТИХІЙ У ПОЕЗІЇ СИЛЬВІЇ ПЛАТ}

Поезія Сильвії Плат стала незаперечним фактом літературного життя англомовного світу, а завдяки численним перекладам, у тому числі і на українську мову, оприявленим впливом на інші літератури. Сильвія Плат належить до тих оригінальних авторів, чиї твори не перестають дивувати читачів та критиків.

Розглядаючи індивідуальну письменницьку манеру Сильвї Плат, ми, безперечно, не можемо оминути суспільно-культурного дискурсу, щзо впливав на семантичне навантаження конщептосфери поетеси. Ï̈ еволючія як Автора прослідковується на прикладі лексичних уподобань, багатства метафор, зростання персонального досвіду, висловленого у текстах. Стаття присвячена характеристииі індивідуального стилю Сильвї Плат та показу цих особливостей на конкретних лінгвістичних прикладах з поетичного доробку письменниці.

У Сильвії Плат в основі метафор лежать релігійні та міфологічні алюзії, факти біографії письменниці, історичні події, сочіальні та культурні явища, природні явища та пов'язані з ними характерні значення. Особливого інтелектуального інтересу заслуговує аналіз втілення ключових для модерної літератури концептів на основі феміністичного та герменевтичного дискурсів у поезї Сильвії Плат, вплив на ї̈ поетичну мову естетичних та ідейних пошуків того часу.

Основні мотиви та образи поетичних творів Сильвї Плат творяться довкола теми жіночої самотності на тлі традииійно-патріархального розуміння її тендерної ролі та персональної фрустрації иієї самотності з використанням широкої палітри виражальних засобів поетичної мови та лінгвоментальних структур, щчо знайшли своє втілення у лексико-семантичних та стилістично-інтонаційних особливостях творчості поетеси.

Ключові слова: дискурс, кониепт, метафора, епічний твір, ліричний герой, алюзія, ідіостиль, семантичне наповнення, концептосфера, авторський стиль.

Olha HORIN, orcid.org/0000-0003-1452-3235 Assistant at the Department of Applied Linguistics Lviv Polytechnic National University (Lviv, Ukraine)zabolotna.olha@gmail.com

Marta HAIDUK, orcid.org/0000-0003-0392-3268 Assistant at the Department of Applied Linguistics

Lviv Polytechnic National University (Lviv,Ukraine) marta.s.haiduk@lpnu.ua 
Tetiana BRYGA, orcid.org/0000-0003-3364-7487 Assistant at the Department of Applied Linguistics Lviv Polytechnic National University (Lviv, Ukraine) tanya.bryga@gmail.com

\section{CONCEPTUAL-POETIC FUNCTION OF THE VOCABULARY ON THE DENOTATION OF NATURAL ELEMENTS IN THE SILVIA PLATH'S POETRY}

Sylvia Plath's poetry has become an indisputable fact of the literary life of the English-speaking world, and thanks to numerous translations, including into Ukrainian, influenced by other literatures. Sylvia Plath is one of those original authors whose works never cease to amaze readers and critics.

Considering the individual writing style of Sylvia Plath, we certainly can't avoid the socio-cultural discourse that influenced the semantic load of the poetess' conceptual sphere. Her evolution as an Author can be traced to the example of lexical preferences, the richness of metaphors, the growth of personal experience expressed in the texts. The article is devoted to the description of the individual style of Sylvia Plath and the exposition of these features on specific linguistic examples from the poetic works of the writer.

In Sylvia Plath works, metaphors are based on religious and mythological allusions, facts about the writer's biography, historical events, social and cultural phenomena, natural phenomena and related characteristic. Particular intellectual interest, deserve the analysis of the implementation of key concepts for modern literature on the basis of feminist and hermeneutic discourses in the poetry of Sylvia Plath, the impact on her poetic language of aesthetic and ideological pursuits of the time.

The main motives and images of Sylvia Plath's poetic works are created around the theme of female loneliness against the background of traditional patriarchal understanding of her gender role and personal frustration of this loneliness using a wide range of poetic language and linguistic structures embodied in lexical-semantic and stylistic-intonation features of the poet's work.

Key words: discourse, concept, metaphor, epic writing, lyrical hero, allusion, idiostyle, semantic content, conceptosphere, author's style.

Аналізуючи творчість будь-якого автора, виражену в текстах, ми звертаємо увагу не лише на смислове поле, сюжетність, вибір тем, культурно-історичний контекст, але й на саму мову, індивідуальний мовленнєвий стиль, специфіку використаної лексики та синтаксичної манери - усе те, що, за визначенням дослідника В. Виноградова, являє собою «мовну особистість». Попри те, що такий термін не всіма дослідниками сприймається як однозначний, він став стрижневим, системостворюючим, інтегративним філологічним поняттям, ключовим в антропоцентричній лінгвістиці (Иванцова, 2010: 25). Особливо актуальним це поняття $є$ для лінгвістичних розвідок, зокрема, у разі вивчення іншомовних авторів та введення корпусу їхніх творів у вітчизняну лінгвокультурологію.

Разом із поняттям «мовна особистість» наприкінці XX - на початку XXI століття все ширше вживаються поняття «ідіостиль» на позначення характерних рис індивідуального мовлення письменника, паралельно використовують такі терміни, як «стиль», «стиль автора», «ідіостиль», «ідіолект», «індивідуальний стиль», «авторський стиль», «авторський ідіолект», що не мають чіткої і прозорої дефініції та критеріїв розмежування. Для глибшого аналізу специфіки індивідуальної лінгвопоетичної манери Сильвії Плат використання поняття «ідіостиль» виглядає для нас продуктив- ним та доцільним. Як зазначає українська дослідниця: «Кожний дослідник тексту змушений так чи інакше розглянути проблему авторського чи індивідуально стилю. Адже «індивідуальний почерк» автора, його манера виявляється вже у самому факті вибірковості, перевазі певних лексичних, морфологічних, синтаксичних, фонетичних засобів, які стають базою формування більш складних і яскравих образів. 3 урахуванням антропоцентризму сучасної наукової парадигми проблема індивідуального стилю стає однією з ключових у лінгвостилістиці художнього тексту. Проте лінгвісти і досі не мають одного загальновизнаного терміна для тлумачення індивідуального стилю, хоча він не раз ставав предметом дослідження (Волошук, 2008: 5).

Система змістових та формально лінгвістичних особливостей текстів Сильвії Плат неодноразово привертала увагу критиків і дослідників. Індивідуальна манера письма Сильвії Плат дозволяє віднести іï до представників ідіосинкратичного напряму в американській поезії, що виробили власний своєрідний стиль, котрий поєднує традиційні форми 3 експериментаторством (Хрущ, 2012: 308).

Як влучно зазначає українська дослідниця перекладознавчих проблем А. Пермінова, розглядаючи особливість перекладів О. Забужко вибраних поезій Сильвії Плат, «ії деколи зовсім недбалий стиль $є$ доказом прагнення бути максимально 
простою й традиційною в плані вираження. Функція форми в дихотомії «форма-зміст» полягає лише в полегшенні сприйняття читачем трансцендентних матерій. Форма іiї віршів - це тілесна оболонка, крізь яку прагне прорватися вища субстанція. Не добираючи слів, зухвало ставлячись до зовнішньої маніфестації змісту, Плат має за звичку обривати вірші на пів думці. Тому іiї поезії нагадують перетяті жили, з яких скрапують слова. $<\ldots>$ Поезія Плат - це суцільний гротеск, нашарування антиномій. Вона наче зумисне уникає напівтонів, намагаючись досягти максимальної чіткості й прозорості думки» (Пермінова, 2002: 214-215).

Дослідники творчості Сильвії Плат відзначають підвищену цікавість авторки до природних стихій, тваринного та рослинного світів, що дає можливість прослідкувати за тим, як зміни в духовній діяльності письменниці впливають на спосіб моделювання нею навколишнього світу.

У контексті дослідження образної системи творів Сильвії Плат доволі цікавими є вірші з образами бджіл. Ці вірші утворюють цикл, всередині якого твори об'єднані єдиною образною темою бджільництва та бджіл, а також формальною схожістю у використанні строф з п’яти рядків. До віршів цього циклу належать такі твори: “Тhe Bee Meeting” Зустріч бджіл, “The Swarm” Бджолиний рій, "The Arrival of the Bee Box" Прибуття вулика, "Stings" Укуси, "Wintering" Зимівля. Поява цього мотиву у віршах Сильвії Плат не випадкова. Як зазначає C. Гілберт (S. Gilbert), Отто Плат, батько авторки, був видатним ентомологом, автором численних праць про комах, серед яких найбільш відомою працею є "Bumblebees and Their Ways" (Gilbert, 1978).

Бджоли символізують у поезії Сильвії Плат знеособлення жінок у патріархальному суспільстві: "The bees are all women, Maids and the long royal lady" Бджсли ие всі жінки, служниці та тривала королева.

Образ бджолиного рою асоціюється у Плат iз знеособленим натовпом, що протиставлений образу матки - королеви бджіл. У вірші “Тhe Bee Meeting" за розумною бджолиною королевою полюють мешканці села:

The villagers open the chambers, they are hunting the queen. Is she hiding, is she eating honey? She is very clever.

She is old, old, old, she must live another year, and she knows it
Селяни відкривають кімнати, вони полюють на королеву.

Вона ховається, їсть вона мед?

Вона дуже розумна. Вона стара, стара, стара, вона повинна прожити ще один рік, $\mathrm{i}$ вона знає це.
Відкривши вулики, вони прагнуть замінити королеву «новими незайманими»: "While in their fingerjoint cells the new virgins".

В останніх рядках голос ліричної героїні та королеви бджіл зливаються:

I am exhausted, I am exhausted -

Pillar of white in a blackout of knives.

I am the magician's girl who does not flinch.

The villagers are untying their disguises, they are shaking hands.

Whose is that long white box in the grove, what have they accomplished, why am I cold

Я втомлена, я виснажена Стовп білого в щільні ножів.

Я чаклунка, яка не здригнеться.

Селяни знімають маскування, вони тиснуть руки.

Чия це довга біла коробка в гаю, чого вони домоглися, чому так холодно мені

Спостерігаємо, що образ королеви набуває трагічного забарвлення, зливаючись 3 мотивом смерті.

У поезії "Stings" королева бджіл зображена старою, з обірваними крилами та тілом, вкритим потертими ворсинками: “... she is old / Her wings torn shawls, her long body/ Rubbed of its plush - Poor and bare and unqueenly and even shameful" ... вона стара / ї крила як порвана шаль, ї довге тіло/ зношене як плюш - i голе, $і$ бідне, $і$ некоролівське, $i$ навіть ганебне.

Але й у такому стані королева бджіл протиставляється «крилатим повсякденним жінкам, котрі збирають мед». У своєму останньому польоті королева бджіл надзвичайно прекрасна: "Where has she been, With her lion-red body, her wings of glass?" Де вона була з ї̈ червоно-лев'ячим тілом, із крилами зі скла? Авторський епітет "lion-red" слугує не лише засобом гіперболізації образу бджоли, але й пов'язує його з образом левиці, котра прокинулася в покірній жінці і вбиває володаря чоловіка у вірші “Stings”. А далі бджола літає над вуликом-мавзолеєм, що убив іiі.

\begin{tabular}{l|l} 
Now she is flying & Тепер вона літає \\
More terrible than she & Ще страшніше, ніж \\
ever was, red & коли-небудь, червоний \\
Scar in the sky, red & шрам у небі, червона \\
comet & комета \\
Over the engine that & Над двигуном, \\
killed her - & який убив їі - \\
The mausoleum, the & Мавзолей, восковий \\
wax house & будинок
\end{tabular}


Образ королеви бджіл у такому разі нагадує нам образ рудоволосої жінки, котра повстає з попелу та поїдає чоловіків, немов повітря, у останніх рядках поезіï "Lady Lazarus": "Out of the ash/I rise with my red hair/And I eat men like air".

Особливої активності та емоційності набуває в поезіях Сильвії Плат семантична площина вода життя, репрезентована здебільшого концептами краса і спокій. Вірш "Aquatic Nocturne" має оригінальну графічну форму: рядки у восьми строфах 3 дев'яти (окрім останньої) центровані, при цьому кожна починається 3 малої літери. Це перегукується з назвою вірша. Глибина подана за допомогою метафори світла, звуку і кольору води. Художньо-семантична сфера вода - краса реалізується за допомогою метафори світла, звуку і кольору води.

Колір води у Сильвії Плат - темно-синій або чорний, що пов'язано з іншим складником - світлом (або його відсутністю). Темний колір при-

Black lake, black boat, two black, cut-paper people. Where do the black trees go that drink here?

Their shadows must cover Canada.

A little light is filtering from the water flowers.

Their leaves do not wish us to hurry:

They are round and flat and full of dark advice.

Cold worlds shake from the oar.

The spirit of blackness is in us, it is in the fishes.

A snag is lifting a valedictory, pale hand;

Stars open among the lilies.

Are you not blinded by such expressionless sirens?

This is the silence of astounded souls.

«Поверхня води» вночі спокійна, вдень на морі шторм. Стан «поверхні води» важливо відзначити у тих віршах, де ліричними героями $\epsilon$ люди. В “Channel Crossing” (Перетинаючи канал) 3 людьми на паромі поверхня води передається через відчуття людей, котрі зазнають хитавиці: шторм символізує життєві негаразди та труднощі, підкреслює безпорадність та розгубленість людей перед бурхливою стихією.

Зовсім інша - спокійна - поверхня води у вірші "Crossing the Water". У цьому вірші, який поетеса написала незадовго до смерті, актуалізується метафора «ріка життя».

«Тваринний світ» представлено морськими мешканцями. Поетеса захоплюється красою підводного світу, зображуючи морських мешканців і передаючи тонкі відтінки їх забарвлення. Вірш "Aquatic Nocturne" (Водний ноктюрн) демонструє широкий спектр кольорів: від сріблястого, 3 сутній у назві вірша "Aquatic Nocturne". У цьому вірші темно-синій колір представлений лексемою “indigo". Індиго, як відомо, отримують 3 рослин. Таким чином, колір індиго розвиває тему природи. Мотиви природи містяться також і в метафорі "turquoise slivers" бірюзові скалки, за допомогою якої описуються тонкі промені місячного світла, проникаючого крізь товщину морської води.

У вірші "Crossing the Water" актуалізується семантичне наповнення темна вода-зневіра. Пара здійснює нічну прогулянку по озеру. Як відзначають дослідники, цей образ перегукується з темною водою у філософії даосизму, де він пов'язаний з мотивами смерті, а також уявленнями давніх про те, що людина по темній воді потрапляє в царство снів та мрій. У цьому вірші домінує прикметник кольору "black". Цей епітет передає не лише темряву, яка оточує людей, котрі пливуть у човні, але i їхній похмурий та подавлений настрій:

Чорне озеро, чорний човен, два

Силуети, вирізані з чорного паперу.

Куди ідуть чорні дерева, щоб пити тут?

Їх тіні повинні охоплювати Канаду.

Легке світло пробивається крізь озерні квіти.

Їм не хочеться, щоб ми поспішали:

Вони круглі та плоскі і повні темної поради,

Весло трясе холодні світи.

Дух чорноти і в нас, і в рибах,

Корч підіймається в прощанні, бліда рука;

Зірки відкриті серед лілій.

Чи не осліп ти

Від цих мовчазних сирен,

Це мовчання здивованих темрявою душ.

яким порівнюється риб'яча луска (“tilting silver”) до виноградно-синього ("grapeblue mussles"). Також представлені і відтінки зеленого: "darkly olive lobsters" темно-оливкові раки та "milk-green jellyfish" молочно-зелена медуза.

Художньо-семантичне наповнення краса - pyx реалізується за допомогою дієслів руху та кваліфікуючих рух атрибутивних конструкцій: "pale flounder waver by", "eels twirl", "adroit lobsters amble", "mobile jet" «бліда камбала коливалася», «вугри вертілися», "спритні омари рухалися інохіддю», «рухливі струмені».

Поетеса постає як спостерігач, тонко помічає повадки морських мешканців. Реалізується ще одна художньо-семантична сфера краса - форма. Уявлення про форму створюється різними засобами i визначається зовнішнім виглядом самої тварини. Форма може бути передана поетичними засобами. Особливо красномовним і виразним є опис медузи, 
форма якої (куля, парасолька) представлена більш досконалою: "the lunar globes of bulbous jellyfish" місячні глобуси ииибулинних медуз. Поетеса захоплюється досконалістю форми цих істот, свідченням чого $є$ семантична надмірність: у словосполученні тричі повторюється характерна ознака «має форму кулі» ("lunar", "globes", "bulbous").

3 наведених прикладів випливає, що невід'ємним елементом концепту водного простору є людина. Ця тема пов'язана не лише 3 антропоморфними ознаками, якими наділяється вода, але й представлена як взаємодія людини і води - перетин водного простору на паромі і човні. У всіх віршах реалізується художньо-семантична сфера людина - елемент живої природи.

Зв'язок з людиною може бути опосередкованим через алюзії, що свідчить про багатоплановість концептів. Як приклад виступає епічний твір Гомера
«Одіссея», індикаторами якого є море і сирени. Проте слово "sirens" (сирени) має різну смислову інтерпретацію. Так, у вірші "Channel Crossing" 3 криком сирен порівнюється завивання штормового вimpy: "wind sirens caterwaul". З'являється концептуальна пара сирени-попередження.

Образ сирен з'являється і у вірші “Crossing the Water". Яскравість образу створюється за рахунок метафори, яка пов'язана 3 переходом зі сфери зорових у сферу слухових відчуттів: “Are you not blinded by expressionless sirens?”. Можна вибудувати асоціативний ланцюжок: безмовність сирен безмовність ночі - темна ніч - небезпека, сполучена як із сиренами, так і з нічним часом доби.

У вірші “I am Vertical” лірична героїня порівнює себе $з$ деревами та квітами, і відзначає свою непричетність до порядку речей, встановленого природою:
I am not a tree with my root in the soil Sucking up minerals and motherly love So that each March I may gleam into leaf... And a flower-head not tall, but more startling...
Адже я не дерево $з$ корінням в грунті

Яке тягне мінерали разом з материнською любов'ю землі.

Отже, кожного березня я можу спалахнути листям...

А квітка зовсім не висока, але така вражаюча...

Sometimes I think that when I am sleeping /I must most perfectly resemble them.

Але істинне злиття 3 природою можливе лише через смерть. Лірична героїня заявляє: And I shall be useful when I lie down finally: / Then the trees may touch me for once, / and the flowers have time for mе. I я буду корисною, коли нарешті ляжу в землю, / Тоді дерева зможуть торкнутися мене, / і у квітів буде час для мене.

Як ми бачимо, традиційне та новаторське одночасно поєднання образів природи, зокрема природних стихій, та емоційних станів у контексті персоніфікованого досвіду та міфологічного дискурсу за допомогою філологічного інструментарію створює лінгвопоетичну індивідуальність творчості Сильвії Плат.

\section{СПИСОК ВИКОРИСТАНИХ ДЖЕРЕЛ}

1. Иванцова Е. В. О термине «языковая личность»: истоки, проблемы перспективы использования. Вестник Томского государственного университета. Серия «Филология», 2010. № 4(12). С. $25-32$.

2. Волошук В. І. Індивідуальний авторський стиль, ідіолект, ідіостиль : питання термінології. Наукові праці. Філологія. Мовознавство. Том 92, випуск 79. Вид-во ЧНУ імені Петра Могили. Миколаїв. 2008, С. 5-8.

3. Хрущ Л. М. Гендерні особливості поезії Сильвії Плат та Єлізабет Бішоп. Наукові записки. Серія філологічна. Національний університет «Острозька академія». Острог, 2012. Вип. 27. С. 308-309.

4. Пермінова А.В. Поезія Сильвії Плат в перекладах Оксани Забужко. Питання літературознавства. 2002. Вип. 9. С. 214-215. URL: http://nbuv.gov.ua/UJRN/P1 2002950 (дата звернення: 21.10.2021).

5. Gilbert S. A Fine, White Flying Myth: Confessions of a Plath A $\bar{d}$ dict. Massachusettes Review, Autumn. 1978.

6. Усі цитування здійснюються за виданням: Plath S. The collected poems. HarperCollinsPublishers, New York, United States, 2018. 384 p. 


\section{REFERENCES}

1. Ivantsova E. V. O termine "yazyikovaya lichnost": istoki, problemyi, perspektivyi ispolzovaniya [On the term "linguistic personality": origins, problems, prospects of use]. Collection of Tomsk State University. Series "Philology". 2010. No. 4 (12). Pp. 25 E.V. 32 [in Russian].

2. Voloshuk V. I. Indyvidualnyi avtorskyi styl, idiolekt, idiostyl: pytannia terminolohii [Individual author's style, idiolect, idiostyle: questions of terminology]. Scientific works. Philology. Linguistics. Volume 92, issue 79. Published by Petro Mohyla National University. Mykolaiv. 2008, pp. 5-8 [in Ukrainian].

3. Khrushch L. M. Henderni osoblyvosti poezii Sylvii Plat ta Yelizabet Bishop [Gender features of poetry by Sylvia Platt and Elizabeth Bishop]. Scientific notes. Philological series. National University "Ostroh Academy". Ostroh, 2012. Issue. 27. Pp. 308-309 [in Ukrainian].

4. Perminova A. V. Poeziia Sylvii Plat v perekladakh Oksany Zabuzhko. [Poetry of Sylvia Plat in Oksana Zabuzhko's translations]. Questions of literary criticism. 2002. Issue 9. Pp. 214-215. Retrieved from: http://nbuv.gov.ua/UJRN/ Pl_2002_9_50 [in Ukrainian] (Last accessed: 21.10.2021).

5. Gilbert S. A Fine, White Flying Myth: Confessions of a Plath Addict. Massachusetts Review, Autumn. 1978.

6. All citations are made according to the publication: Plath S. The collected poems. HarperCollinsPublishers, New York, United States, 2018. 384 p. 